\title{
Article \\ Fire-Environment Analysis: An Example of Army Garrison Camp Williams, Utah
}

\author{
Scott M. Frost ${ }^{1}$, Martin E. Alexander ${ }^{2}$, R. Justin DeRose ${ }^{3, *}$ and Michael J. Jenkins ${ }^{1}$ \\ 1 Department of Wildland Resources, Utah State University, Old Main Hill, Logan, UT 5230, USA; \\ scott.m.frost@gmail.com (S.M.F.); mjenkins@powdermountain.com (M.J.J.) \\ 2 Wild Rose Fire Behaviour, 180-50435 Range Road 232, Leduc County, AB T4X 1L0, Canada; mea2@telus.net \\ 3 Department of Wildland Resources and Ecology Center, Utah State University, Old Main Hill, Logan, \\ UT 5230, USA \\ * Correspondence: justin.derose@usu.edu; Tel.: +1-435-797-0242
}

Received: 8 February 2020; Accepted: 5 March 2020; Published: 9 March 2020

\begin{abstract}
The planning of fuel treatments for ecological or societal purposes requires an in-depth understanding of the conditions associated with the occurrence of free-burning fire behavior for the area of concern. Detailed fire-environment analysis for Army Garrison Camp Williams (AGCW) in north-central Utah was completed as a prerequisite for fuel treatment planning, using a procedure that could be generally applied. Vegetation and fuels data, topographic and terrain features, and weather and climate data, were assessed and integrated into predictive fuel models to aid planning. A fire behavior fuel model map was developed from biophysical variables, vegetation type, and plot survey data using random forests, and resulted in an overall classification rate of $72 \%$. The predominate vegetation type-fuel complex was grass, followed by lesser amounts of Gambel oak, Wyoming big sagebrush and Utah juniper. The majority of AGCW is mountainous in nature, characterized by slopes less than $40 \%$ in steepness with slightly more northerly and easterly aspects than south and west, and elevations that ranged from 1650 to $1950 \mathrm{~m}$ above mean sea level. Local fire weather data compiled from the three nearest remote automated weather stations indicated that average temperature maxima $\left(32{ }^{\circ} \mathrm{C}\right)$ and relative humidity minima $(12 \%)$ usually occurred between 1400 to $1500 \mathrm{~h}$ daily, and from July to August, seasonally. The semi-arid climate at AGCW, coupled with the corresponding preponderance of flashy fuel types and sloping terrain, constitutes a formidable fire environment in which to plan for mitigating against adverse fire behavior.
\end{abstract}

Keywords: fire climate; fire weather; fuel model; potential fire behavior; random forests; remote automated weather station; topography

\section{Introduction}

Large fires $(400 \mathrm{ha}+)$ occur about every seven to ten years in the vegetation types located at the U.S. Army Garrison Camp Williams (AGCW) practice range, located in north-central Utah (Figure S1). In 2010 and 2012, for example, wildfires burned beyond the boundaries of AGCW into the adjacent wildland-urban-interface (WUI). The political and public reaction to these fire escapes were intense. However, in the context of WUI fire protection, the configuration of topography and local weather patterns in AGCW is extremely problematic. Prevailing winds and the steepest slopes tend to align along the northern ridge of the AGCW, immediately south of the burgeoning WUI. To further complicate matters, this same area is dominated by shrubby Gambel oak (Quercus gambellii Nutt.) on southern exposures - which was precisely the location where a fuelbreak was breached in 2010 by the Machine Gun Fire that subsequently burned multiple structures in the community of Herriman, Utah. Given the predictability of topographic controls, weather, and the predominance of flashy fuels on 
potential fire behavior, a system of fuel treatments could be developed to prevent future fire escapes at AGCW, and elsewhere, based on an analysis of the fire environment.

Understanding of the interactions of fire and its environment (i.e., the surrounding conditions, influences or forces that influence or modify fire behavior) was the name for a concept first coined by Countryman [1]. He considered it one of the keys to the effective control of wildfires and successful use of prescribed fire in wildland management. The term fire environment represents the synergy that occurs amongst fuel, topographic and air mass or weather factors that influence the inception, growth, and behavior of a wildland fire [1-7]. The fire environment can be represented by an inverted isosceles triangle (Figure 1). The two lower sides of the triangle represent the fuel and topographic components of the fire environment. The top side represents the air mass or weather component of the fire environment. The current state of each of these environmental components and their interactions with each other and with the fire itself, determine the characteristics and behavior of a fire at any given moment.

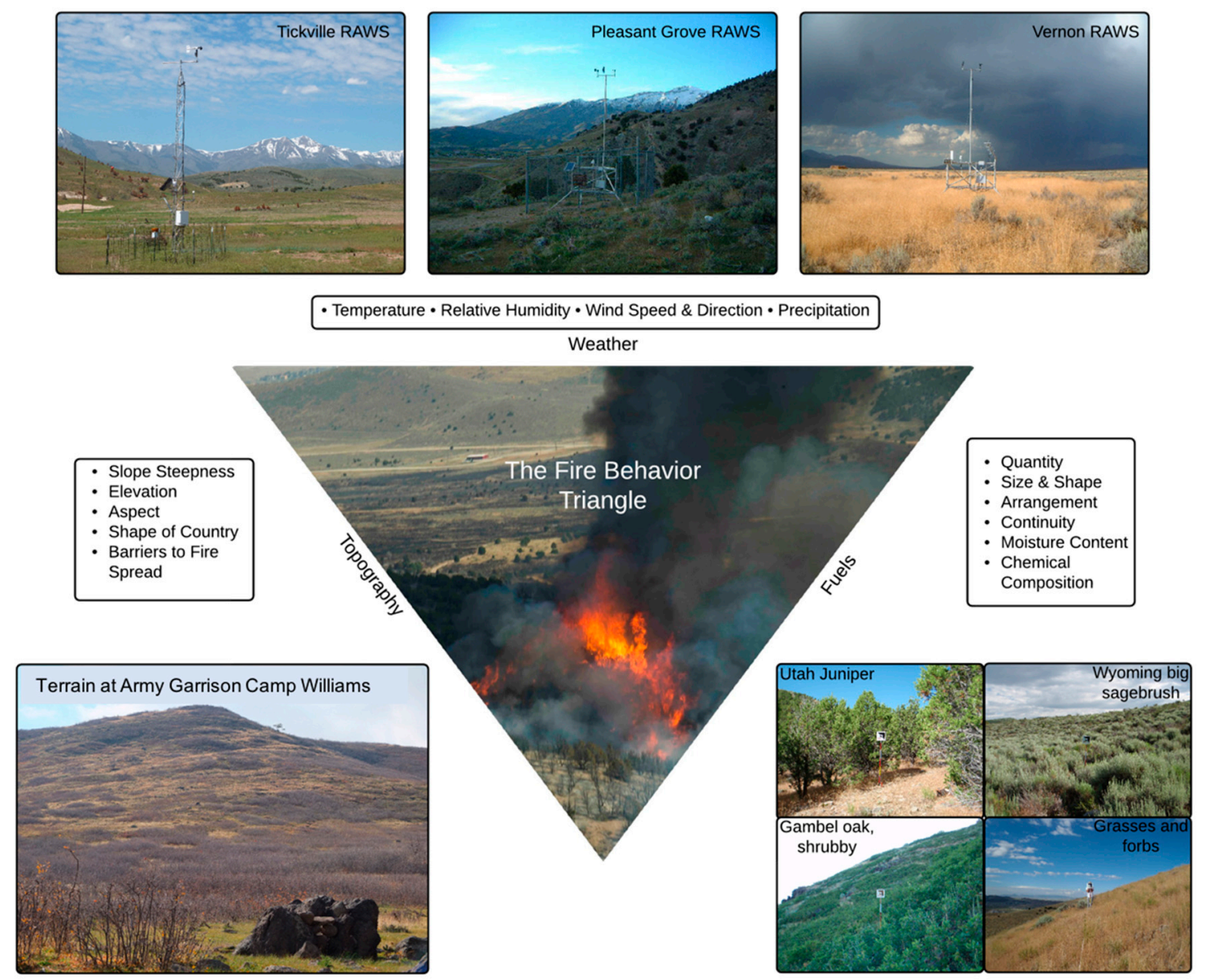

Figure 1. Photos of the fuels (lower right), weather (upper), and topography (lower left) at Army Garrison Camp Williams illustrating the three components of the fire environment triangle [3] that in turn form the fire behavior triangle as outlined by [1].

Other factors important to fire behavior must always be considered in relation to fuels for "In short, no fuel, no fire!" [8]. Wildland fuels are created by living and dead plant materials through biological processes, photosynthesis, decomposition and accumulation [9]. Wildland fuels are vegetation viewed from the standpoint that they affect the behavior of wildfires and prescribed fires [8]. Certain individual vegetation types are commonly viewed as a fuel type, i.e., "an identifiable association of fuel elements of distinctive species, form, size, arrangement, and continuity that will exhibit characteristic fire behavior 
under defined burning conditions" [10]. A fire behavior fuel model (FBFM hereafter), on the other hand, is a simulated fuel complex for which all the fuel descriptors (e.g., loading and surface area-to-volume ratio by fuel size, fuelbed depth) required for the solution of the Rothermel [11] mathematical rate of spread model have been specified [12].

Changes in the moisture content of woody fuels is dependent on the particle diameter and environmental conditions. Small diameter fuels respond relatively quickly to changing weather conditions whereas large diameter fuels require a longer drying or wetting trend to impact fuel moisture. The diameters of woody fuel particles are commonly classified according to their time-lag (TL), i.e., the length of time required for a fuel particle to lose about $63 \%$ of the difference between its initial moisture content and its equilibrium moisture content $[13,14]$. The TL categories conventionally used in the U.S. for wildland fire modeling are specified as 1-, 10-, 100-, and 1000-h TLs and correspond to round wood diameter size-class ranges of 0-0.635 (fine or flash fuels), 0.635-2.54 (medium or intermediate fuels), 2.54-7.62 (heavy or coarse fuels), and >7.62 (large fuels) cm, respectively [11,15,16].

Terrain, or topography, the orientation of the land surface or exposure, is determined by the steepness or inclination of the slopes and by the aspect or the azimuth of the slope. The characterization of topography also incorporates elevation, natural and man-made barriers to fire spread, and shape of the country $[17,18]$. These factors affect fire behavior in one or more ways. The effect of slope on fire spread is to increase the efficiency in preheating fuels and, in turn, the rate of the advancing flame front. All other things being equal, with respect to the fire environment, a fire burning on a $30 \%$ slope will spread approximately two times faster than a fire on level ground [19]. With the exception of the mechanical effect of slope steepness on rate of fire spread, the effect of topography on fire behavior depends largely on how it alters both the meso- and micro-scale meteorological variables and how these influence changes in dead fuel moistures and winds near the ground surface [20-22].

Weather is the most dynamic component of the fire environment, varying greatly, both temporally (in terms of months, days, hours, and minutes) and spatially. The influence of a weather element on fire behavior can be direct, as with the case of wind speed on fire spread rate and wind direction on the direction the fire is heading. It can also have an indirect influence, as is the case in determining dead fuel moistures in which wetting and drying effects are controlled by past and present variations in air temperature, relative humidity, solar radiation and precipitation [23]. Conversely, moisture levels in living plants are controlled by plant phenology and season; they generally have very little to do directly with weather conditions, except in the case of extended droughts.

The objective of this paper was to: (1) provide an in-depth analysis of the three individual components comprising the fire environment, using AGCW as an example, by assembling and processing the available data on vegetation (fuels), terrain, and weather in the area [24] and (2) characterize the steps necessary to conduct a thorough fire environment analysis for any wildland system. This process constitutes a prerequisite for the interpretation of wildland fire behavior potential that uses existing model systems and guidelines. In doing so, we identify the characteristics of potential fire behavior, and, in turn, fire impacts and effects, that can be estimated as functions of fuel, terrain, and weather [25].

\section{Materials and Methods}

\subsection{Study Area}

The AGCW is located within the Great Basin fire climate region [20], which is typified by cold winters, hot summers, and low annual precipitation $(40-100 \mathrm{~cm})$. The climate of the AGCW is heavily influenced by the rain shadow effect of the Sierra Ranges partially driven by the Great Basin High wind pattern that originates in Canada and the Northwest. This wind pattern warms adiabatically as air masses move from the high elevations of the Sierra and Cascade ranges to the drier and lower elevations of the Great Basin. Surface pressures tend to be flat in the Great Basin summer months, allowing for extended periods of high ambient air temperatures, low relative humidities, and extreme 
air mass instability [20]. Precipitation occurs mostly in the winter months with a secondary peak in the spring.

\subsection{Vegetation and Fuels}

For vegetation and fuel mapping, at AGCW we implemented a standard suggested by Keane et al. [26], the "vegetation triplet," a combination of (1) biophysical data that characterizes important governing environmental factors and context, (2) species composition data characterizing typical vegetation type or cover, and (3) vertical stand structure data, which characterizes the typical height and dimensions of the vegetation. Data for mapping vegetation and fuels at AGCW were developed using the Light Detection and Ranging (LiDAR) data obtained in 2011 over AGCW that included: LiDAR-derived biophysical data; LiDAR-derived vegetation height; high-resolution orthoimagery (HRO) $(15 \mathrm{~cm}$ ); and a normalized difference vegetation index layer (NDVI) (Figure 2). Two sets of plot data were used for the classifications. The first set were field data collected by AGCW resource management personnel in 2012 on 91 plots using Natural Fuel Photo Series guides [27-30] to classify vegetation strata. Additionally, each plot was classified as a FBFM according to the classification of [31]. Further plots were added to the original 91 plots using GIS and visually interpreted from the same HRO layer used in the mapping process to supplement under-represented FBFM categories. The second set of plot data were derived by generating 1000 random data points within a GIS framework that were then classified into dominant vegetation type categories of either Gambel oak, Utah juniper (Juniperus osteosperma (Torr.) Little), Wyoming big sagebrush (Artemesia tridentate Nutt. ssp. wyomingensis Beetle \& Young), grass or bare earth; common grass species at AGCW include cheatgrass (Bromus tectorum L.), needle-and-thread grass (Hesperostipa comata (Trin. \& Rupr.) Barkworth), bulbous bluegrass (Poa bulbosa L.), Sandberg bluegrass (P. secunda J. Presl), western wheatgrass (Pascopyrum smithii (Rydb.) Á. Löve), blue bunch wheatgrass (Pseudoroegneria spicata (Pursh) Á. Löve) and Indian rice grass (Stipa hymenoides Roem. \& Schult.).

Utilizing plot data, two spatially classified maps were produced for AGCW, one for FBFMs and one for dominant vegetation types. To map the vegetation at AGCW, five categories corresponding to dominant vegetation were used: bare earth, grass, sagebrush, juniper, and Gambel oak. To map the FBFMs, Anderson's classification [32] was used as opposed to Scott and Burgan [31]. This approach was taken because the live fuel moisture inputs for the respective FBFMs in Anderson's classification represents the 'worst case' or driest possible conditions [33] and thus represented a conservative effort to avoid an under-prediction bias in judging potential fire behavior.

For mapping purposes, the random forests classification method [34] was used because it is ideally suited to the non-linear and complex interaction variables employed in the classification. The random forests classification constructed hundreds of decision trees and returned the class predicted by the majority of the trees, before the final model was applied to the spatial data on a per-pixel basis. To produce each map, 500 trees were used for every prediction, with three variables used at each split. The geospatial raster layers used as predictors in random forests were identical for both the dominant vegetation type and FBFM.

We evaluated model fit for both maps using variable importance plots and the Gini Index. A large difference in variable importance indicated the most influential variables selected during model building. The random forests classification recursively selected $60 \%$ of the data to predict the remaining $40 \%$, referred to as the out-of-bag data. The mean decrease in accuracy was determined during the out-of-bag error estimation. The larger the accuracy decreased with the addition of a single variable, the more important the variable was deemed by the random forests model. Similarly, the Gini index indicated how each variable contributed to the homogeneity in the nodes and leaves of the random forest classification. Scaled from 0 to 1, and multiplied here by 100, the Gini index indicated poor predictors, that had a homogeneous response close to 0 , and the best predictors that had a more heterogeneous response close to 1 . As with mean decrease in accuracy, the greater the decrease in the Gini index, the more important the variable. 


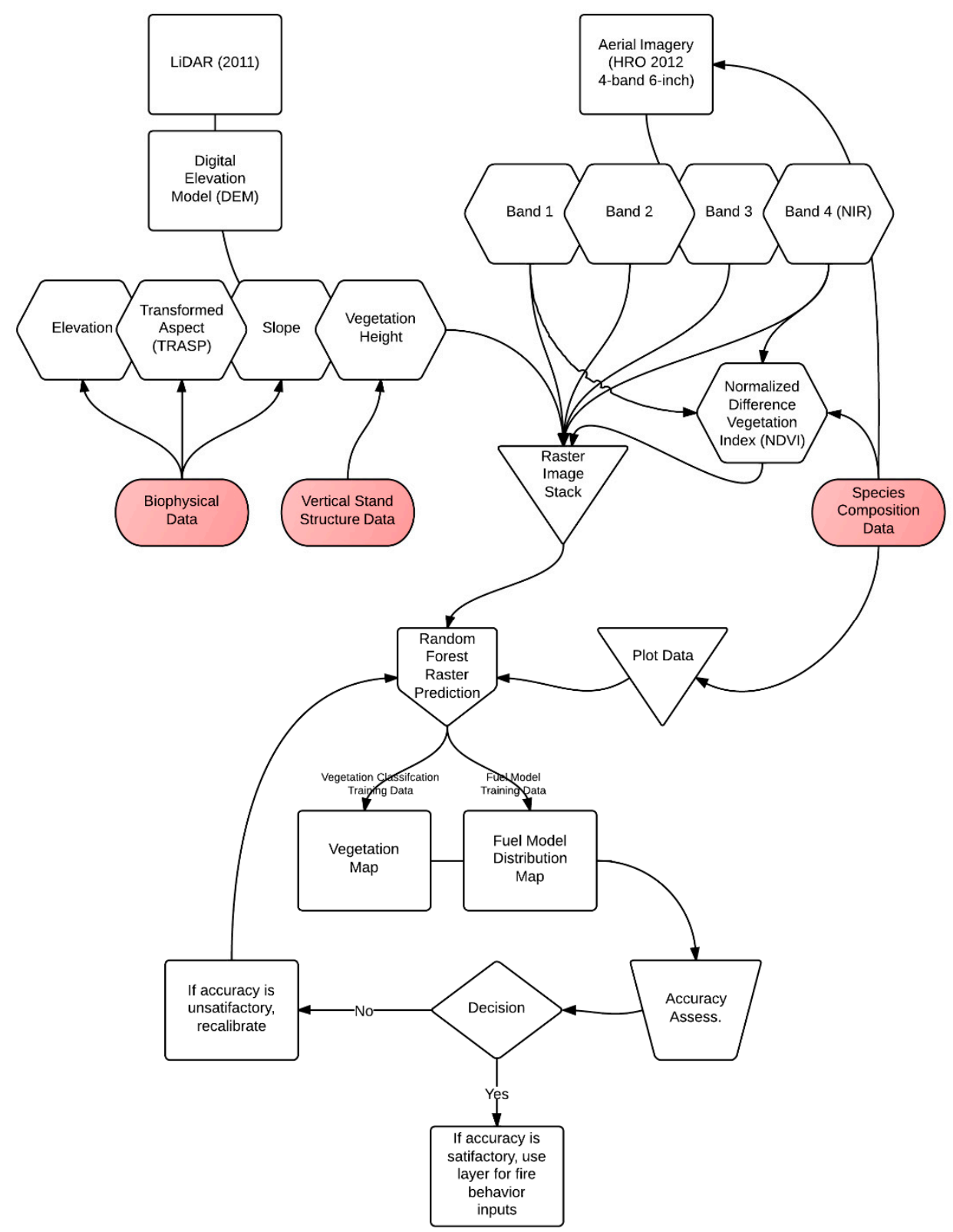

Figure 2. Flow chart of methodology used to map vegetation types and Anderson [32] fire behavior fuel models at Army Garrison Camp Williams. Red boxes indicate the three vegetation triplet categories of [26]. LiDAR = light detection and ranging, $\mathrm{HRO}=$ high resolution orthoimagery and $\mathrm{NIR}=$ near infrared.

As no sampling of live herbaceous and woody fuel moistures was carried out within AGCW, it was necessary to compile live fuel moisture data from the National Fuel Moisture Database [35] for the dominant vegetation corresponding to dominant vegetation types occurring within AGCW located at adjacent sampling sites (Figure S1, Table 1). The four different vegetation types available from the National Fuel Moisture Database applicable to AGCW were cheatgrass, Wyoming big sagebrush, Gambel oak and Utah juniper. Sampling for live fuel moistures were generally collected on a bi-monthly basis. 
Table 1. Characteristics of live fuel moisture sampling sites in Utah near Army Garrison Camp Williams selected for analysis and available years of data.

\begin{tabular}{|c|c|c|c|c|c|}
\hline Site & Latitude & Longitude & $\begin{array}{l}\text { Elevation } \\
\text { (m MSL) }\end{array}$ & Vegetation & $\begin{array}{l}\text { Years of } \\
\text { Record }\end{array}$ \\
\hline Squaw Peak & $40^{\circ} 18^{\prime} \mathrm{N}$ & $111^{\circ} 37^{\prime} \mathrm{W}$ & 2038 & Gambel oak & 2002-2013 \\
\hline Sevier Reservoir & $39^{\circ} 35^{\prime} \mathrm{N}$ & $112^{\circ} 00^{\prime} \mathrm{W}$ & 1624 & Cheatgrass & 2002-2013 \\
\hline Vernon & $40^{\circ} 03^{\prime} \mathrm{N}$ & $112^{\circ} 19^{\prime} \mathrm{W}$ & 1719 & $\begin{array}{c}\text { Utah juniper, Wyoming } \\
\text { big sagebrush }\end{array}$ & 1997-2013 \\
\hline
\end{tabular}

\subsection{Topography}

To better understand the topography or terrain of AGCW, the LiDAR data was processed using QT Modeler 8.01 [36] into return categories and graphically analyzed using a Geographic Information System (GIS) via ArcGIS 10.1 [37]. An important post-processing raster product was a high resolution $(0.5 \mathrm{~m})$ digital elevation model (DEM), a representation of the Earth's surface (Figure S2). From the DEM layer, slope steepness and aspect rasters were also derived. The areas involved with individual topographic characteristics were calculated using the zonal statistics geoprocessing tool in ArcGIS 10.1 [37].

While a wide variety of slope steepness classifications exist, e.g., [17], we used the five slope classes associated with the National Fire Danger Rating System [38]: 0-25, 26-40, 41-55, 56-75 and >75\%. As for aspect or slope exposure, the four major cardinal directions (north, east, south and west) were defined as per [39]. For elevation, five classes were delineated on the basis of 150-m intervals starting at $1500 \mathrm{~m}$ mean sea level (MSL) with the final class set at $2100 \mathrm{~m}$ MSL.

\subsection{Weather and Climate Data}

Weather data were gathered from the three nearest remote automated weather stations (RAWS) to AGCW (Figure S1, Table 2). Data from the Pleasant Grove and Vernon RAWS sites were used to provide a longer temporal window and to fill in missing time periods for the more local Tickville RAWS. Readings for weather data were initiated $15 \mathrm{~min}$ before the hour and represented 10-min averages which are reported on the hour. RAWS hourly data were recorded according to local standard time [40] with no time adjustment for changes in daylight savings time. Trends in diurnal variation were averaged by hour and month at the Pleasant Grove RAWS for March 1 to October 31 for the period 1997 to 2013. While this station was not the closest in proximity to AGCW, it provided a longer record of weather data.

Table 2. Characteristics of remote automated weather stations selected for analysis and available years of data.

\begin{tabular}{cccccc}
\hline Weather Station & Latitude & Longitude & $\begin{array}{c}\text { Elevation } \\
\text { (m MSL) }\end{array}$ & No. of Years & Years of Record \\
\hline Tickville & $40^{\circ} 24^{\prime} \mathrm{N}$ & $112^{\circ} 00^{\prime} \mathrm{W}$ & 1582 & 11 & $2000-2001$, \\
Pleasant Grove & $40^{\circ} 25^{\prime} \mathrm{N}$ & $111^{\circ} 45^{\prime} \mathrm{W}$ & 1585 & 17 & $2004-2010,2012-2013$ \\
Vernon & $40^{\circ} 05^{\prime} \mathrm{N}$ & $112^{\circ} 25^{\prime} \mathrm{W}$ & 1676 & 23 & $1997-2013$ \\
\hline
\end{tabular}

RAWS data were processed using Fire Family Plus [41] and the R Statistical Package [42] to summarize diurnal and seasonal trends for ambient air temperature, relative humidity, 6.1-m open wind speed, 1-, 10-, and 100-h dead fuel TL fuel moistures (Figure 3) during the fire season (defined here as March 1 to October 31). Eighty-four percent of the 27,906 fires that occurred in Utah from 1992 to 2012 happened during this time frame [43]. For diurnal data, observations were averaged according to month and hour of the day for the time span of each RAWS weather record. Seasonal data were averaged by month for each RAWS according to the same timeframe. Seasonal trends were computed 
for each RAWS and then averaged. The fire weather variables analyzed were ambient air temperature, relative humidity $(\mathrm{RH}), 6.1-\mathrm{m}$ open wind speed, and dead fuel moisture TL size-classes.

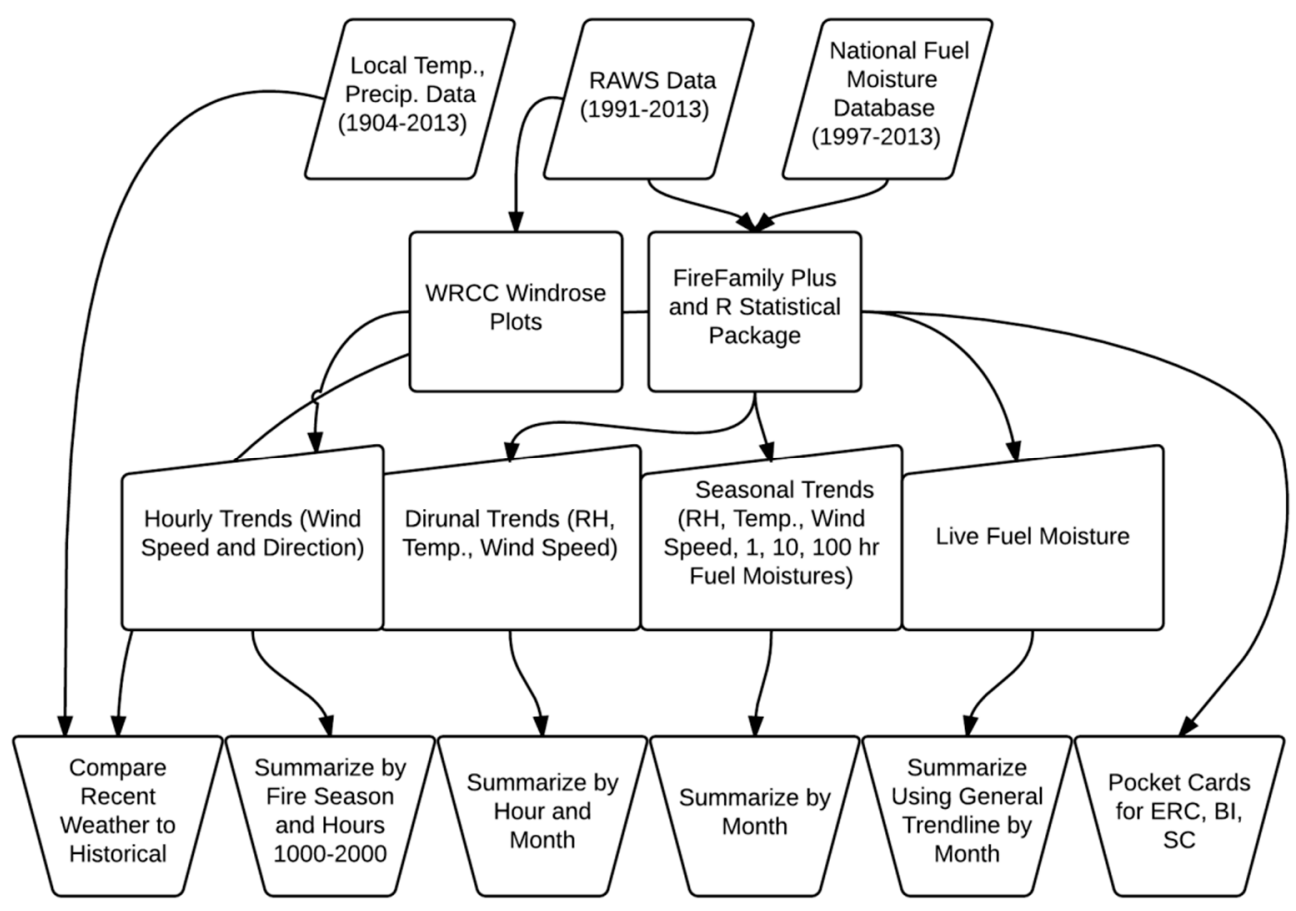

Figure 3. Flow chart of methodology used to summarize weather using remote automated weather station (RAWS) data, local weather observation data, and National Fuel Moisture Database live fuel moisture content data. $\mathrm{RH}=$ relative humidity, $\mathrm{ERC}=$ energy release component, $\mathrm{BI}=$ burning index, $\mathrm{SC}=$ spread component and WRCC $=$ Western Regional Climate Center.

Wind rose diagram or plots were generated from the Western Regional Climate Center (WRCC) [44] for each RAWS. Data for the wind rose plots were queried to average observations that occurred between 1000 to $2000 \mathrm{~h}$ during the fire season. The wind rose plots are designed to show the distribution of wind directions experienced at a given location — they thus show the prevailing wind direction [45] - the most common format is a circle from which 8 or 16 lines are estimated, 1 for each compass point with the percentage for calm conditions noted in the center. The average 6.1-m open wind speed and direction available from the WRCC [44] were summarized for the three RAWS locations within and near AGCW, with wind speed ranges classified according to the Beaufort wind force scale [46]. Data for the wind rose plots were filtered to present a summary only for the main burning period each day (1000 to 2000 h) from March to October.

Historical climate data were obtained via the NOAA National Climatic Data Center [47] from a nearby climatological station (1373 m MSL) on the northern end of Utah Lake (Figure S1), approximately $10 \mathrm{~km}$ south of AGCW. The data ranged from 1904-2013 and were used to compare precipitation and ambient air temperature trends over various multi-year periods. The historical weather data at Utah Lake were averaged by month for the years 1904-1930, 1931-1960, 1961-1990, and 1991-2013, from January to December.

\subsection{Fire Behavior Prediction Tools}

Fire danger rating pocket cards [48] specific to AGCW were also produced using FireFamily Plus [41] to estimate the Energy Release Component (ERC) Burning Index (BI), and Spread Component (SC) of the NFDRS. The ERC is a measure of the total heat release per unit area, the BI is an indication of suppression difficulty related to flame length at the head of a fire, while SC is a rating of the forward 
rate of spread at the head of a fire [40]. A photo interpretation guide depicting the representative vegetation type associated with the FBFMs was developed for implementation within the AGCW.

\section{Results}

\subsection{Vegetation and Fuel Modeling}

Overall validation for the vegetation classification was $64.0 \%$ with a Kappa of $47.3 \%$ (Figure 4, Table S1), which was modest according to typical remote sensing standards. A matrix of vegetation class distribution by NFDRS slope classes further indicated the area of AGCW distributed by vegetation (Table S1) and slope (Table 3). By far, the largest proportion of vegetation was classified as grass $(34.1 \%)$, and was primarily located within the $0-25 \%$ slope class, secondarily (13\%) in the $26-40 \%$ slope class, and tertiary $(7.9 \%)$ in the $41-55 \%$ slope class (Table 3). Fifteen percent of total vegetation was classified as Gambel oak. Gambel oak and grass were the most prominent vegetation in the highest slope categories, however, this constituted approximately three percent of total vegetation at a slope steepness of $56 \%$ or greater (Table 3). Variable importance and Gini index plot for the vegetation map indicated that $\mathrm{HRO}$ band 1 was the single most important predictor, followed closely by LiDAR, which represented vegetation height (i.e., the difference from the first return data minus the bare earth data, Figure 5). That no clear separation occurred between the most important variables was likely a product of modest model performance (Table S1).

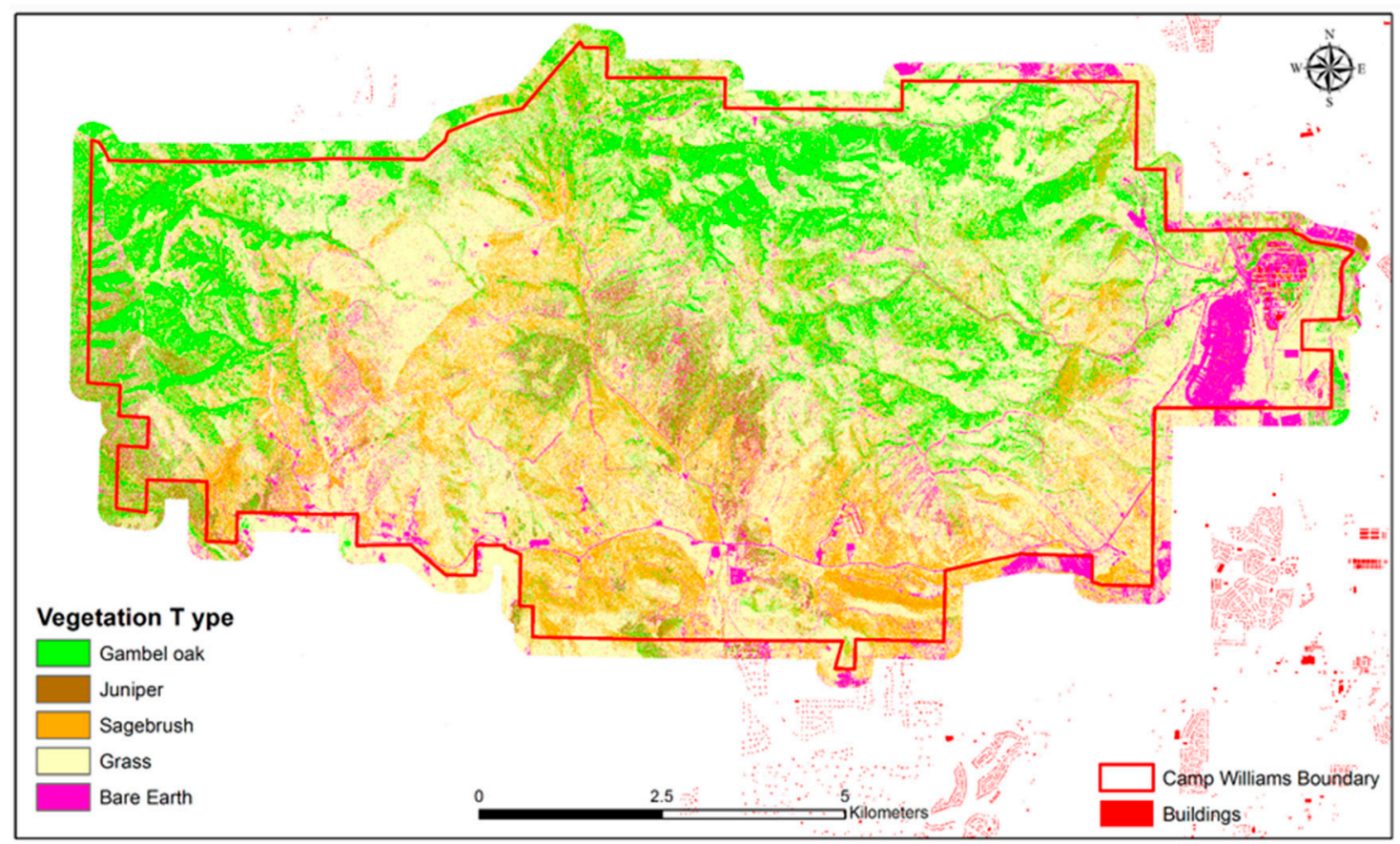

Figure 4. Spatial depiction of vegetation at Army Garrison Camp Williams predicted using random forests at $0.5 \mathrm{~m}$ resolution. 
Table 3. Matrix of vegetation class distribution within the National Fire Danger Rating System (NFDRS) slope steepness classes at Army Garrison Camp Williams.

\begin{tabular}{ccccccc}
\hline \multirow{2}{*}{ Vegetation Type } & \multicolumn{7}{c}{ NFDRS Slope Steepness Class (\%) } \\
& $\mathbf{0 - 2 5}$ & $\mathbf{2 6 - 4 0}$ & $\mathbf{4 1 - 5 5}$ & $\mathbf{5 6 - 7 5}$ & $\mathbf{7 5 5}$ & Area (ha) \\
\hline Gambel oak & 5.0 & 5.9 & 4.7 & 2.3 & 0.4 & 2027 \\
Juniper & 1.9 & 1.0 & 0.6 & 0.2 & 0.0 & 419 \\
Sagebrush & 7.7 & 3.1 & 1.2 & 0.4 & 0.1 & 1405 \\
Grass & 34.1 & 13.6 & 7.9 & 2.7 & 0.3 & 6529 \\
Bare earth & 4.9 & 1.0 & 0.6 & 0.3 & 0.1 & 751 \\
Slope class percentage & 53.7 & 24.6 & 15.0 & 5.9 & 0.9 & 11,130 \\
\hline
\end{tabular}
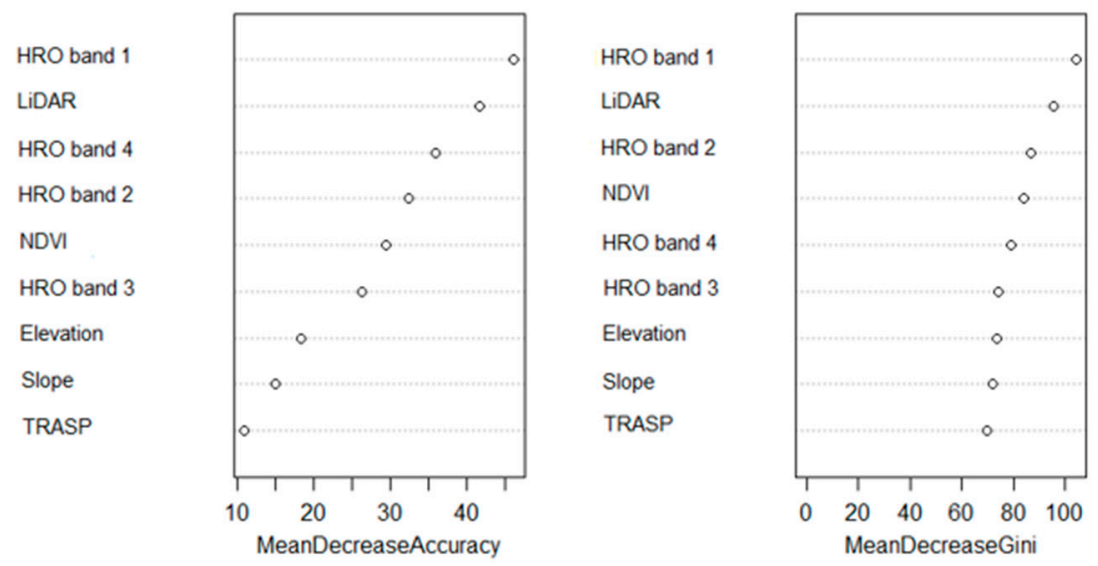

Figure 5. Mean decrease for variable importance and Gini index for the vegetation map product. LiDAR = height of vegetation from light detection and ranging values determined by taking first return values minus bare earth values, HRO band 1-4 = high resolution orthoimagery taken from bands 1-4, respectively. NDVI = normalized difference vegetation index and TRASP $=$ transformed aspect.

Overall validation for the FBFM classification map was $72.3 \%$ with a Kappa coefficient of $57.1 \%$ (Figure 6, Table 4). The mean decrease in accuracy for the variable importance plot and the Gini index indicated that the LiDAR values were the most important for prediction accuracy, followed by $\mathrm{HRO}$ bands 1,4, and the NDVI (Figure 7). In addition to the classification map, the fuel model distribution by NFDRS slope classes was produced (Table S2). FBFMs 5 and 2 were the most abundant at 4073 and 3815 total ha, respectively. FBFM 1 (2008 total ha) was almost entirely allocated in 0-25\% slope class $(12.8 \%)$, and $3.3 \%$ in the $26-40 \%$ slope class. FBFMs 5 and 2 had the largest proportion of area classified in slope classes of $41 \%$ and greater, with a total of $12.9 \%$ for FBFM 5 and a total of 4.4\% for FBFM 2.

Table 4. Matrix of fire behavior fuel model (FBFM) class distribution by National Fire Danger Rating System (NFDRS) slope steepness classes at Army Garrison Camp Williams.

\begin{tabular}{ccccccc}
\hline \multirow{2}{*}{ FBFM } & \multicolumn{7}{c}{ NFDRS Slope Steepness Class (\%) } \\
& $\mathbf{0 - 2 5}$ & $\mathbf{2 6 - 4 0}$ & $\mathbf{4 1 - 5 5}$ & $\mathbf{5 6 - 7 5}$ & $\mathbf{> 7 5}$ & Area (ha) \\
\hline 1 & 12.8 & 3.3 & 1.5 & 0.4 & 0.0 & 2008 \\
2 & 22.9 & 7.0 & 3.5 & 0.9 & 0.1 & 3815 \\
5 & 11.5 & 12.2 & 8.5 & 3.8 & 0.6 & 4073 \\
8 & 0.6 & 0.5 & 0.4 & 0.2 & 0.1 & 199 \\
$99 *$ & 5.9 & 1.6 & 1.1 & 0.5 & 0.1 & 1034 \\
Slope class percentage & 53.7 & 24.6 & 15.0 & 5.9 & 0.7 & 11,130 \\
\hline
\end{tabular}

Note: ${ }^{*}$ FBFM $99=$ Bare earth [31]. 


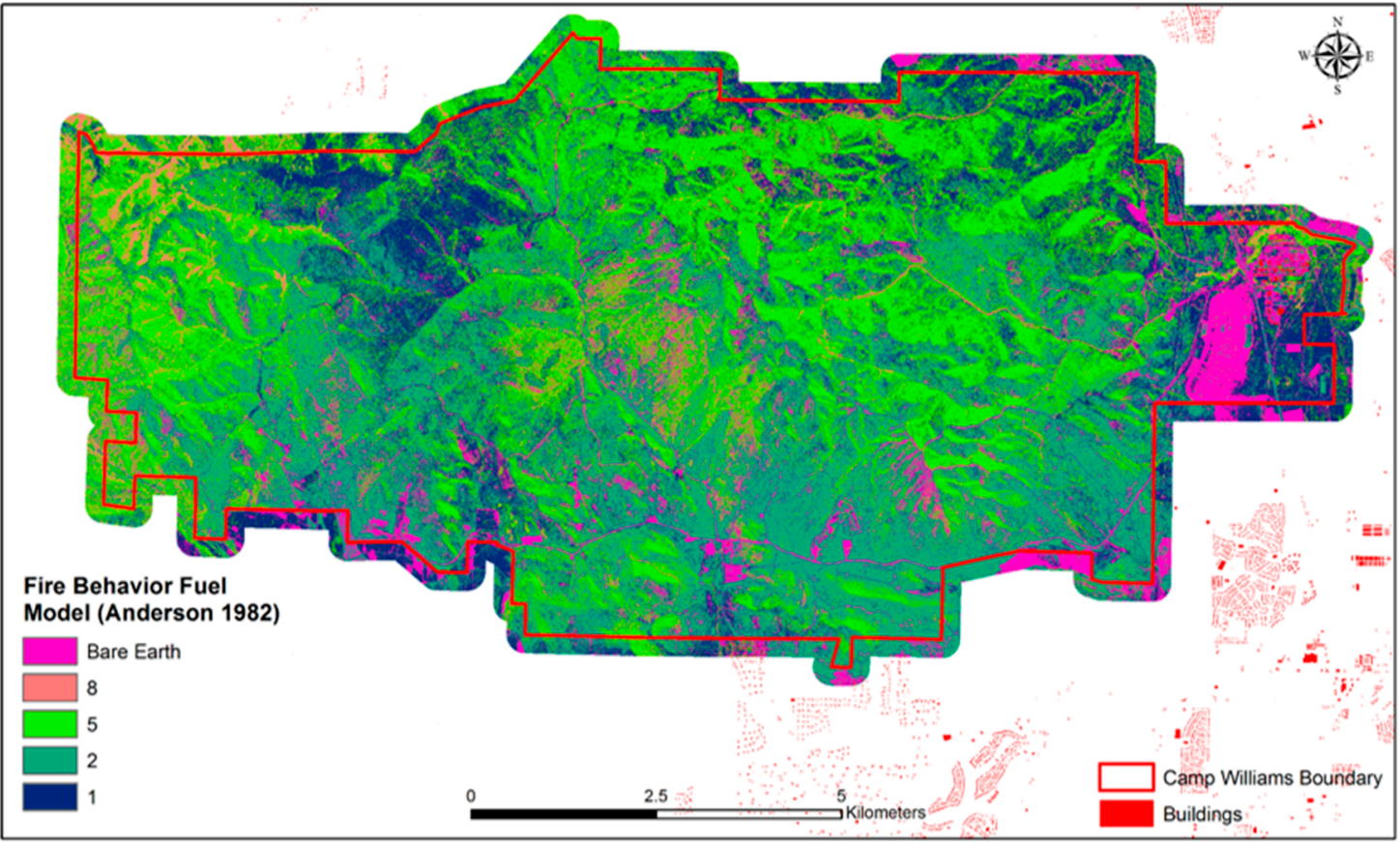

Figure 6. Map of Anderson [32] fire behavior fuel models for Army Garrison Camp Williams as predicted using random forests at $0.5 \mathrm{~m}$ resolution.
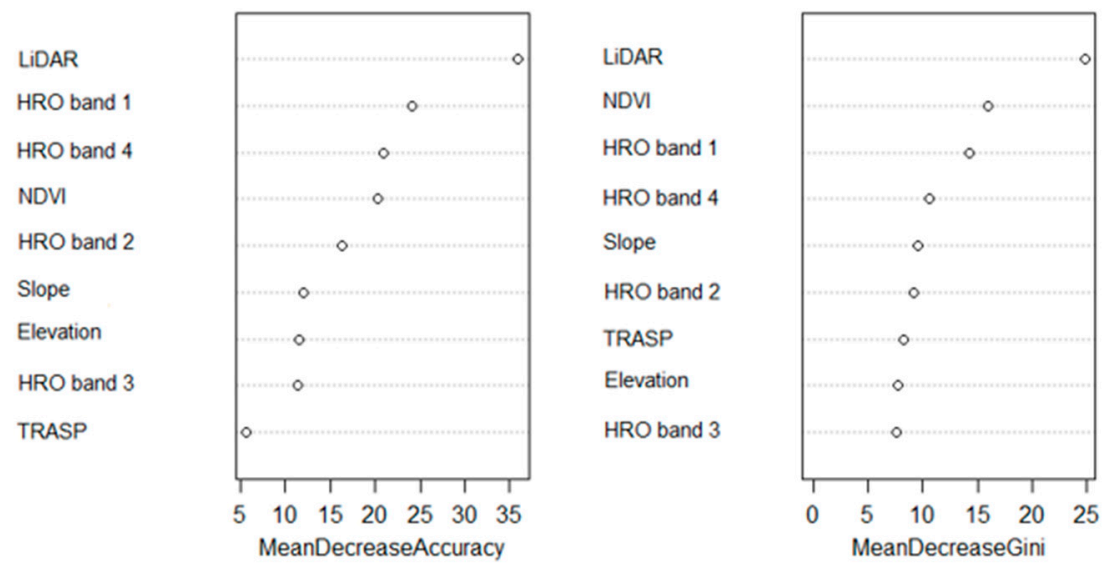

Figure 7. Mean decrease for variable importance and Gini impurity for the Anderson fire behavior fuel model [32] map product at Army Garrison Camp Williams. LiDAR = height of vegetation from light detection and ranging values determined by taking first return values minus bare earth values, HRO band 1-4 = high resolution orthoimagery taken from band 1-4, respectively. NDVI = normalized difference vegetation index, and TRASP = transformed aspect.

Fuel Moisture

Annual variation in live herbaceous fuel moistures estimated for AGCW were extremely variable (Figure S3). Cheatgrass values were generally within one standard deviation of their average. Wyoming big sagebrush live fuel moisture varied considerably, with values in the spring nearly $200 \%$ of dry weight, before they decreased to lows that ranged from 60 to $100 \%$. Similar to Wyoming big sagebrush, Gambel oak fuel moistures were very high in the spring, from $150 \%$ to $220 \%$, before they decreased over the summer to lows of $60 \%$ to $100 \%$ from August to October. Utah juniper fuel moistures were generally less variable, but typically ranged from about $63 \%$ to $85 \%$ throughout the fire season. Seasonal variations in the dead fuel time-lag size classes (i.e., 1-, 10- and 100-h), indicated that, like live fuel, dead fuel moisture content was high in the spring (March, April, and May), but gradually decreased 
each month to seasonal lows that were reached in July and August (Figure S4). After August, dead duel moisture content increased nominally during the latter part of the fire season (i.e., September and October).

\subsection{Topography}

A majority of the terrain in AGCW was characterized by slopes from $0 \%$ to $40 \%$ slope ( $78 \%$ of total area), with the remaining $22 \%$ characterized by steep slopes of $41 \%$ or greater (Table 5 ). The breakdown of aspect categories revealed that a large portion of the base has north- and east-facing aspects $(62 \%)$ as opposed to south and west aspects (38\%). Elevation was most typically between 1650 to $1950 \mathrm{~m}$ MSL ( $85 \%$ of total area). Elevation at AGCW was highest on the western and northwestern boundaries at elevations near 2100 m MSL (Figure S2).

Table 5. Area estimates of topographic and fuel characteristics incorporating a $250 \mathrm{~m}$ buffer surrounding the Army Garrison Camp Williams boundary.

\begin{tabular}{|c|c|c|}
\hline Fire Environment Characteristic & Area (ha) & Percent of Total Area (\%) \\
\hline \multicolumn{3}{|l|}{ NFDRS slope steepness range } \\
\hline $1=0-25 \%$ & 5976 & 53.7 \\
\hline $2=26-40 \%$ & 2734 & 24.6 \\
\hline $3=41-55 \%$ & 1670 & 15.0 \\
\hline $4=56-75 \%$ & 653 & 5.9 \\
\hline $5=>75 \%$ & 96 & 0.9 \\
\hline \multicolumn{3}{|l|}{ Aspect } \\
\hline North & 3540 & 31.8 \\
\hline East & 3334 & 30.0 \\
\hline South & 2046 & 18.4 \\
\hline West & 2210 & 19.9 \\
\hline \multicolumn{3}{|l|}{ Elevation (m MSL) } \\
\hline $1500-1649$ & 665 & 6.0 \\
\hline 1650-1799 & 2619 & 23.5 \\
\hline 1800-1949 & 4312 & 38.8 \\
\hline 1950-2099 & 2529 & 22.7 \\
\hline$>2100$ & 1005 & 9.0 \\
\hline \multicolumn{3}{|l|}{ Vegetation type } \\
\hline Gambel Oak & 2027 & 18.2 \\
\hline Juniper & 419 & 3.8 \\
\hline Sagebrush & 1405 & 12.6 \\
\hline Grass & 6529 & 58.7 \\
\hline Bare Earth & 751 & 6.7 \\
\hline \multicolumn{3}{|l|}{ Fire behavior fuel model } \\
\hline 1-Short grass $(0.3 \mathrm{~m})$ & 2008 & 18.0 \\
\hline 2-Timber (grass and understory) & 3815 & 34.3 \\
\hline 5-Brush $(0.6 \mathrm{~m})$ & 4073 & 36.6 \\
\hline 8-Closed timber litter & 199 & 1.8 \\
\hline Bare earth & 1034 & 9.3 \\
\hline
\end{tabular}

NFDRS = National Fire Danger Rating System

\subsection{Weather and Climate}

\subsubsection{Temperature}

Diurnal variation in ambient air temperature was lowest at $0900 \mathrm{~h}$, and average maximum occurred around $1500 \mathrm{~h}$ (Figure S5). Hourly temperatures were greatest from June to August, and reached about $32{ }^{\circ} \mathrm{C}$ at $1500 \mathrm{~h}$ in July. As hourly values were aggregated and averaged over multiple years, they do not capture the large individual variation in temperature. For example, the maximum hourly temperature recorded between the three RAWS sites from the available data were $42{ }^{\circ} \mathrm{C}$ in July 
of 2003. Seasonal temperature peaked in July near $32{ }^{\circ} \mathrm{C}$ at the Vernon RAWS, $33^{\circ} \mathrm{C}$ at the Pleasant Grove RAWS, and $26^{\circ} \mathrm{C}$ at the Tickville RAWS (Figure S6).

\subsubsection{Relative Humidity}

The diurnal variation in $\mathrm{RH}$ revealed that the lowest values occurred as expected during the peak fire season from June to September (Figure S4). The daily variation in RH during July ranged from the average minimum of about $12 \%$ to the average maximum of about $23 \%$. The largest dip in $\mathrm{RH}$ occurred during the daylight hours, typically in the afternoon around $1500 \mathrm{~h}$, and corresponded to maximum daily temperatures at about the same time. Seasonal RH values recorded at all RAWS stations were lowest in June, July, and August, with the lowest observed values in July ( 15\%) at the Vernon RAWS (Figure S7).

\subsubsection{Precipitation}

Average monthly and daily precipitation for the fire season recorded at the Pleasant Grove RAWS indicated a trend of higher average precipitation in the spring months of April and May (Figure S8). On average, precipitation was lowest in June, July, August, and September, whereas July registered the lowest overall amount. Average precipitation increased in October, typically the end of fire season in north-central Utah.

\subsubsection{Wind Speed and Direction}

The diurnal variation in the 6.1-m open wind speed was dramatic in terms of maximum $\left(19 \mathrm{~km} \mathrm{~h}^{-1}\right)$ and minimum $\left(5 \mathrm{~km} \mathrm{~h}^{-1}\right)$ averages, but appeared somewhat consistent by month (Figure S5). The lowest wind speeds during the day, $\left(\sim 5 \mathrm{~km} \mathrm{~h}^{-1}\right)$, occurred in the morning at about $0900 \mathrm{~h}$ regardless of month, except for March and April. Wind speeds typically increased throughout the day after the morning minimum until a short lull that occurred at around 1800 to $2000 \mathrm{~h}$, followed by a subsequent increase, before maximum wind speeds were reached during the night. Maximum daily wind speeds for all three RAWS locations averaged from 15 to $20 \mathrm{~km} \mathrm{~h}^{-1}$ regardless of the fire season month (Figure S5). Seasonal variability in wind speed over the fire season indicated highs over $20 \mathrm{~km} \mathrm{~h}^{-1}$ occurred during the spring, and seasonal lows that varied by RAWS (Figure S9).

The primary directions of wind recorded at the Tickville RAWS was from the southeast, east, and north (Figure S10). Near calm wind conditions (i.e., average wind speeds of less than $1.3 \mathrm{~m} \mathrm{~s}^{-1}$ or $5 \mathrm{~km}$ $\mathrm{h}^{-1}$ ) prevailed for $5.9 \%$ of the days recorded, while about $30 \%$ of the time there was an indication that winds from 1.8 to $3.6 \mathrm{~m} \mathrm{~s}^{-1}$ ( 6.5 to $13 \mathrm{~km} \mathrm{~h}^{-1}$ ) primarily occurred from the east and southeast. Wind speeds from 3.6 to $5.8 \mathrm{~m} \mathrm{~s}^{-1}$ (13 to $21 \mathrm{~km} \mathrm{~h}^{-1}$ ) occurred approximately $30 \%$ of the time, with wind directions typically from southeast, east, and north. Only about $3-5 \%$ of all days had average wind speeds from 8.6 to $14.4 \mathrm{~m} \mathrm{~s}^{-1}$ ( 31 to $52 \mathrm{~km} \mathrm{~h}^{-1}$ ). The highest wind speeds were typically from the southeast, south, north, and northwest.

The primary directions of wind recorded at the Pleasant Grove RAWS were from the southwest, south and west (Figure S11). Near calm conditions occurred about $19 \%$ of the time, while about $20 \%$ of the time, winds of 1.8 to $3.6 \mathrm{~m} \mathrm{~s}^{-1}$ occurred from the primary directions. Approximately $15 \%$ of days exhibited wind speeds between 3.6 to $5.8 \mathrm{~m} \mathrm{~s}^{-1}$, mostly from the south, west, and northwest. Wind speed maximums of 11.2 to $14.4 \mathrm{~m} \mathrm{~s}^{-1}$ ( 40 to $52 \mathrm{~km} \mathrm{~h}^{-1}$ ) were associated with winds from the south.

The primary directions of wind recorded at the Vernon RAWS were southwest, west, and north (Figure S12). Near calm conditions occurred $6.3 \%$ of the time, while about $33 \%$ of the time winds from 1.8 to $3.6 \mathrm{~m} \mathrm{~s}^{-1}$ occurred. Wind speeds from 3.6 to $5.8 \mathrm{~m} \mathrm{~s}^{-1}$ occurred about $30 \%$ of the time, and were almost equally distributed in between the south, southwest, west, northwest, and northern directions. Wind speeds of 5.8 to $8.5 \mathrm{~m} \mathrm{~s}^{-1}$ were recorded about $16 \%$ of the time with a directional distribution to the south, southwest, and north. Wind speeds of 11.2 to $14.4 \mathrm{~m} \mathrm{~s}^{-1}$ rarely occur but when they do, they generally come from the south, southwest, and north. 


\subsubsection{Historical Precipitation and Temperature}

Historical precipitation during the early $20^{\text {th }}$ century was the lowest on record (Figure S13). The period of 1904 to 1930 recorded average annual precipitation of $159 \mathrm{~mm}$, compared to $176 \mathrm{~mm}$ during the period from 1991 to 2013. The period from March to May generally received the highest amount of precipitation, whereas June to August typically received the least.

Historical ambient air temperatures were nearly identical on a monthly basis between weather stations, except for the Tickville and Pleasant Grove RAWS (Figure S14). With each successive multi-year period, temperature increased gradually during the hottest months. For example, from 1904 to 1930 , the maximum average July temperature was about $31.5^{\circ} \mathrm{C}$, increased to about $32{ }^{\circ} \mathrm{C}$ from 1931 to 1990 , and increased again to $33.5^{\circ} \mathrm{C}$ from 1991 to 2013 . This pattern of increasing temperature by multi-year period was also true for June, August, and September.

\subsection{Fire Behavior Prediction Tools}

Dominant vegetation types, fire behavior fuel models, topography, and weather and climate data were organized by important energy release components associated with severe fire years (e.g., 2010 and 2012), and were integrated to develop: (1) a fire danger rating pocket card (Figure A1), and; (2) a FBFM photo interpretation guide (Figure A2), specifically for use at AGCW.

\section{Discussion}

The fire environment analysis for AGCW has indicated that a predominance of flashy fuels, made up of grass and shrub vegetation types, in combination with moderate to steep terrain, coupled with high ambient air temperatures in the afternoon hours during the fire season, collectively constituted a difficult situation for fire-fighting. They also, however, indicate a predictable situation for proactive fuels planning and management. Fire is only possible where vegetation or fuel is present. At AGCW, the vast majority of the installation's land area is vegetated (10,379 ha or $93.3 \%)$ as opposed to non-vegetated (751 ha or $6.7 \%$ ). Of the vegetated area, the most fire prone fuel-topographic situations are Gambel oak on steep slopes. Indeed, Gambel oak was typically represented by FBFM 5 on slopes steeper than $41 \%$. As Gambel oak typically exhibits high fuel moisture content throughout the main part of the fire season, under extreme fire weather conditions (i.e., strong southerly winds, high temperatures, low relative humidities), it can still burn vigorously. Furthermore, given that the large Tickville Valley is oriented in a south-north direction across the central section of the AGCW (Figure S2), this is extremely likely to act as a catalyst for the predominant northerly upslope winds that occur during the hottest hours of the day. Composed primarily of flashy grass, Gambel oak and Utah juniper vegetation that occurs on the southerly exposures, the valley provides continuous fuel, and has historically exhibited extreme fire behavior events (Appendix A). The fire environment analysis indicated that this configuration of vegetation type, topography, and climatic patterns-when paired with critical fire weather conditions-presents an extremely problematic situation for WUI fire protection; in particular, for the newly developed suburban area to the north of AGCW. The approach to fire environment analyses described herein also provides: (1) the basis for enhanced fuels planning and treatment to ensure that future fires in AGCW can be more readily anticipated and controlled and (2) the steps needed to perform similar analyses in other rangeland fire environments.

\subsection{Fuels Planning}

Every attempt should be made to mitigate against the possible occurrence of WUI fires by manipulation of the fuel situation and, in particular considering the potential encroachment of urban development into wildland areas. It is not uncommon for land managers to use the Landscape Fire and Resource Management Planning Tools (LANDFIRE) dataset [49], which is nationally available at a $30 \mathrm{~m}$ resolution and provides geospatial data required by fire behavior and growth simulation software such as FARSITE [50] and FlamMap [51], and provides generalized fire behavior fuel models, 
that are derived from rule sets based on existing vegetation type, cover, height and environmental site potential [49]. Fires are dynamic in nature [52,53], but fuels planning is an important part of mitigating potential risk. Here, we have developed FBFMs that are uniquely tailored to local vegetation, topography, and historical weather measured on or near AGCW. Due to the existence of flashy grass fuels combined with the higher fuel loading of shrub and woodland types, local understanding of fuel arrangement almost certainly gives fuel management better tools to combat fire escapes. For example, at AGCW, Gambel oak occurs primarily on higher elevation slopes and northern aspects, whereas Utah juniper typically occurs only on higher elevation sites, but usually on more exposed southern and western aspects. As Gambel oak is primarily characterized by FBFM 5, efforts can be made to monitor and treat this vegetation type. Similarly, sagebrush at AGCW primarily occurs at lower elevation sites, but in proximity to the naturally flashy grass types. Both of these types were characterized by FBFMs 1 and 2, which are indicative of fuel complexes that readily burn.

\subsection{Weather and Climate}

Local understanding of the predominate weather and climate characteristics for AGCW is paramount for effective placement of fuel treatments, and for effective fire control during conflagrations when they do occur. For example, the AGCW fire environment analysis suggested that the months from June to September were most commonly associated with critical fire weather conditions (i.e., high ambient air temperatures and low relative humidities) and low dead fuel moisture levels that allow for the development of rapidly spreading, high-intensity fires given an ignition source. Furthermore, daily wind speed patterns during the fire season remained fairly constant regardless of month, and are expected to increase in strength throughout the day beginning at $1000 \mathrm{~h}$ and not declining until shortly after midnight.

Data from the historical multi-year ambient air temperature comparisons revealed a trend in increasing temperature. This is consistent with other research [54] which has implicated higher temperatures, longer growing seasons, extended fire seasons, and more days of high fire danger as a result of a warming climate. Weather and fuels data at AGCW should be monitored closely to ascertain patterns in the growth and senescence patterns of vegetation. Each individual fire season is likely to vary considerably, but an expectation of longer fire seasons should not only be incorporated into fuels planning, but also fire-fighting training at AGCW. Warming trends also underscore the need for monitoring of live fuel moisture contents in the dominant vegetation/fuel types located within the AGCW rather than relying on distant sampling sites. Additional weather stations are recommended to supplement existing resources and to provide more localized data for other areas at AGCW (other than the region serviced by the Tickville RAWS), which are highly influenced by topographic conditions. This data will help in future fire and fuels planning efforts by providing the necessary baseline data for determining vegetation responses related to climate.

\subsection{Vegetation and Fuel Model Mapping Limitations}

Prior to our study, there were only two sources of data on FBFMs and their location available for AGCW, both of which were derived from the LANDFIRE classification system, and a local fuel typing classification based on vegetation type [55]. These two data sources have several limitations, including limited verification and the assumption that vegetation type represents a particular FBFM. These were improved upon empirically through our analyses. It is common to base FBFM classifications on descriptions of the fuel complex, including vegetation type, structure and arrangement, as well as on physical descriptions of the fuels themselves. An empirical approach to modeling is easily validated and can enhance professional judgment and familiarity with local burning characteristics in order to refine the planning process and, in turn, more accurately appraise fire behavior potential.

While there have been previous attempts made at FBFM mapping, e.g., [56] to our knowledge, relatively little research has been undertaken to map FBFMs at high resolution in sage steppe ecosystems. The recent availability of LiDAR data has expanded mapping application opportunities and has also 
been used to estimate sagebrush height [57,58]; and to delineate vegetation types [59]. It has yet to be employed in mapping FBFMs in rangelands however. Our fuel modeling efforts were typically on the higher end of moderate agreement; Kappa values between $40 \%$ and $80 \%$ have been suggested as representing moderate agreement between the classification map and the ground reference data [60]. The greatest source of error in our random forests classifications models came from distinguishing between bare earth and sagebrush, and could likely be improved by using additional layers and/or imagery flown on a different date. Regardless, the mapped vegetation and FBFM maps matched the actual vegetation types and FBFMs quite well at a fine spatial resolution $(0.5 \mathrm{~m})$.

\subsection{A Fire Management Application - Fire Danger Rating Pocket Cards}

Fire danger rating pocket cards are visual aids developed to display NFDRS indices and thus encourage situational awareness and safety for local fire fighters [40]. Pocket cards help fire fighters judge the severity of current weather conditions within the context of historical NFDRS ratings, and are developed from historical climatological data for a specific geographic area, like the one developed here for AGCW (Figure A1). Typically, fire danger rating pocket cards are distributed to fire fighters at the beginning of the fire season for reference purposes. Pocket cards usually display seasonal trends in the BI, ERC and SC components of the NFDRS. The historical data used for pocket cards is plotted by month and averaged over the time period of the weather record for quick visual representation of dangerous wildfire conditions. A red horizontal line is often plotted to represent a critical percentile threshold that once crossed, represents the likelihood of extreme fire potential. In addition, specific NFDRS index and component values corresponding to large fire events are plotted (indicated as a star with the fire name) for quick reference. Furthermore, photo interpretive guides specific to FBFMs and their associated vegetation types provide rapid and easily applied decision aids to assess fuel conditions over large areas. The photo interpretive guide presented here (Figure A2) can be readily applied to AGCW.

\section{Concluding Comments}

While our primary objective was to acquire an understanding of the AGCW fire environment in order to gain a better perspective of the associated fire behavior potential, the overall approach constitutes a model framework for future fire behavior modeling and planning, regardless of geographic location. This systematic process could aid fire and fuels planners in establishing an effective fire behavior context before fuel management policies and treatments are implemented. The methodology presented here is an example of a process for fuel management project evaluations, prior to implementation. A thorough understanding of the fire environment will lead to more informed decision-making and, hopefully, more effective fuel treatment implementation, ideally suited for the specific conditions of a specific geographic location.

Supplementary Materials: The following are available online at http://www.mdpi.com/2571-6255/3/1/6/s1, Table S1: Accuracy metrics for random forests vegetation classification map at Army Garrison Camp Williams, Table S2: Accuracy metrics for random forests method applied to the development of the fire behavior fuel model (FBFM) map at Army Garrison Camp Williams based on the Anderson [32] classification, Figure S1: Location of remote automated weather stations, long-term climatological weather station (1904-2013), and fuel sampling sites used in the fire weather component analysis for Army Garrison Camp Williams, Figure S2: Digital elevation model (DEM) applied to Army Garrison Camp Williams illustrating the general landscape features of the area, Figure S3: The seasonal variation in live fuel moisture content percentages extracted from the National Fuel Moisture Database for vegetation types applicable to Army Garrison Camp Williams, Figure S4: The seasonal variation in daily dead fuel moistures for 1-, 10- and 100-h time-lag size classes as computed for $1300 \mathrm{~h}$ from March 1 to October 31 at three remote automated weather stations (RAWS) within and near Army Garrison Camp Williams, Figure S5: Graphical summary of diurnal variation in relative humidity (RH), ambient air temperature (Temp), and 6.1-m open wind speed by month during the fire season at Army Garrison Camp Williams based on the Pleasant Grove remote automated weather station for the period 1997 to 2013, Figure S6: The seasonal variation in the daily ambient air temperature as recorded at $1300 \mathrm{~h}$ from March 1 to October 31 at three remote automated weather stations (RAWS) within and near Army Garrison Camp Williams, Figure S7: The seasonal variations in the daily relative humidity as recorded at $1300 \mathrm{~h}$ from March 1 to October 31 at three remote automated weather stations (RAWS) within and near Army Garrison Camp Williams, Figure S8: Daily and monthly precipitation 
averages recorded at the Pleasant Grove remote automated weather station near Army Garrison Camp Williams from 1997-2013, Figure S9: The seasonal variation in the daily 6.1-m open wind speed as recorded at $1300 \mathrm{~h}$ for the fire season at three remote automated weather stations (RAWS) within and near Army Garrison Camp Williams, Figure S10: Wind rose diagram following the WRCC format for the Tickville remote automated weather station near Army Garrison Camp Williams, Figure S11: Wind rose diagram following the WRCC format for the Pleasant Grove remote automated weather station east of Army Garrison Camp Williams, Figure S12: Wind rose diagram following the WRCC format for the Vernon remote automated weather station southwest of Army Garrison Camp Williams, Figure S13: Monthly averages for precipitation for multi-year periods at the Utah Lake climatological station and Pleasant Grove and Vernon remote automated weather stations, Figure S14: Monthly averages of ambient air temperature for multi-year periods at the Utah Lake climatological station and Pleasant Grove and Vernon remote automated weather stations.

Author Contributions: Conceptualization, S.M.F., M.E.A. and M.J.J.; data curation, S.M.F.; formal analysis, S.M.F.; funding acquisition, M.E.A., and M.J.J.; investigation, S.M.F., M.E.A. and M.J.J.; methodology, S.M.F., M.E.A. and M.J.J.; project administration, M.J.J.; supervision, M.E.A. and M.J.J.; writing—original draft, S.M.F.; writing - review and editing, M.E.A., R.J.D. and M.J.J. All authors have read and agreed to the published version of the manuscript.

Funding: This research was supported by funding from the Utah National Guard, Army Garrison Camp Williams. This research was supported by the Utah Agricultural Experiment Station, Utah State University, and approved as journal paper number 9283 .

Acknowledgments: Much thanks to Chris McGinty, Ben Crabb, and Chris Garrard for their technical assistance. We thank Doug Johnson and Sean Hammond of the Utah National Guard for their help in providing guidance throughout the research process. Lastly, thanks to Doug Ramsey, Dave Thomas, Cyndi Sidels, Faith Ann Heinsch, and Daniel Huisjen for their guidance and review of the fire behavior modeling aspects of the study.

Conflicts of Interest: The authors declare no conflict of interest.

\section{Appendix A}

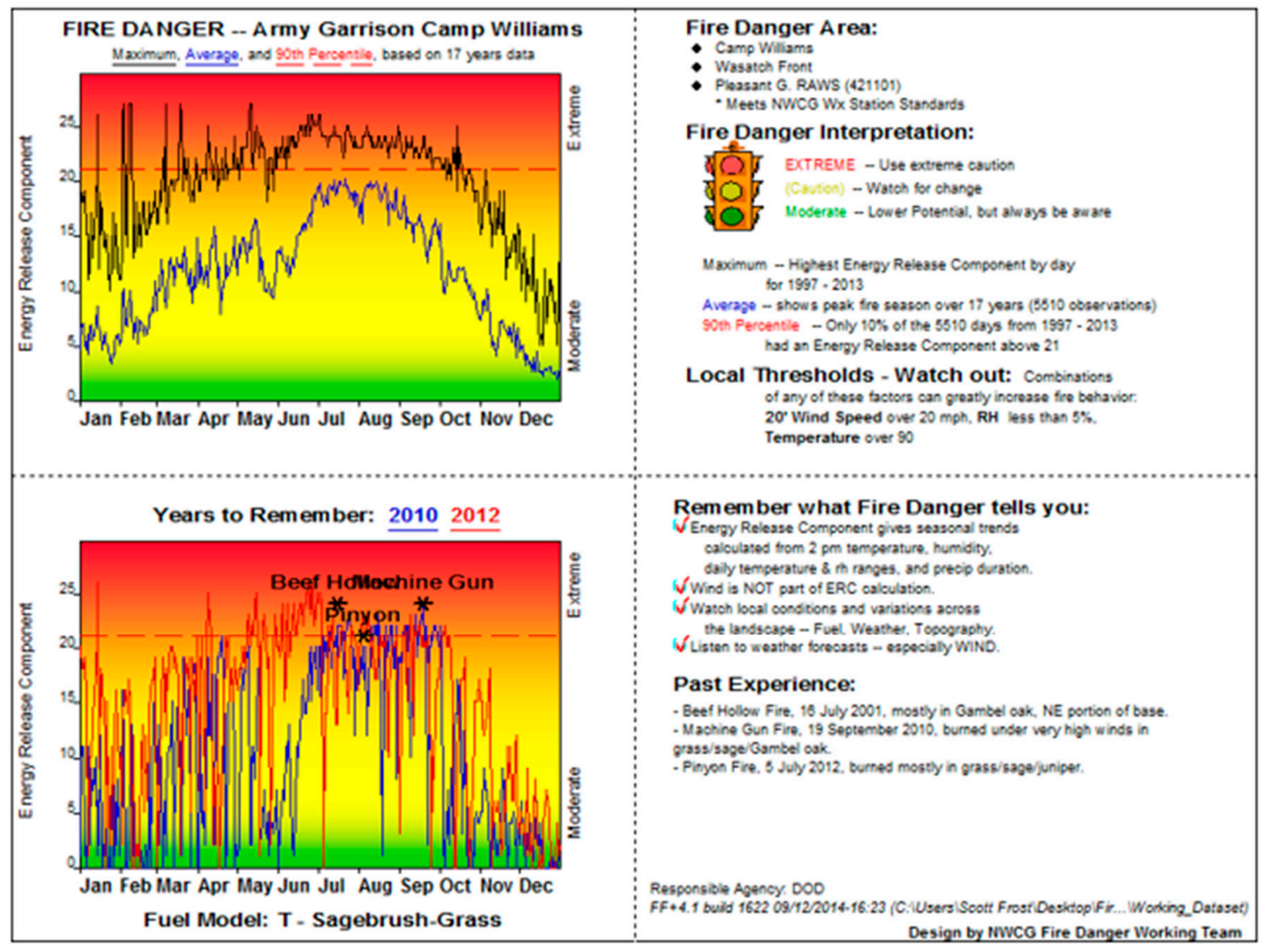

Figure A1. Fire danger rating pocket card, produced from remote automatic weather station (RAWS) climatological data recorded near Army Garrison Camp Williams. 90 $0^{\text {th }}$ percentile Energy Release Component are displayed as a red-dotted line. On the bottom plot, two specific years when large fires occurred in 2010 (Machine Gun Fire) and 2012 (Pinyon Fire) are displayed. 


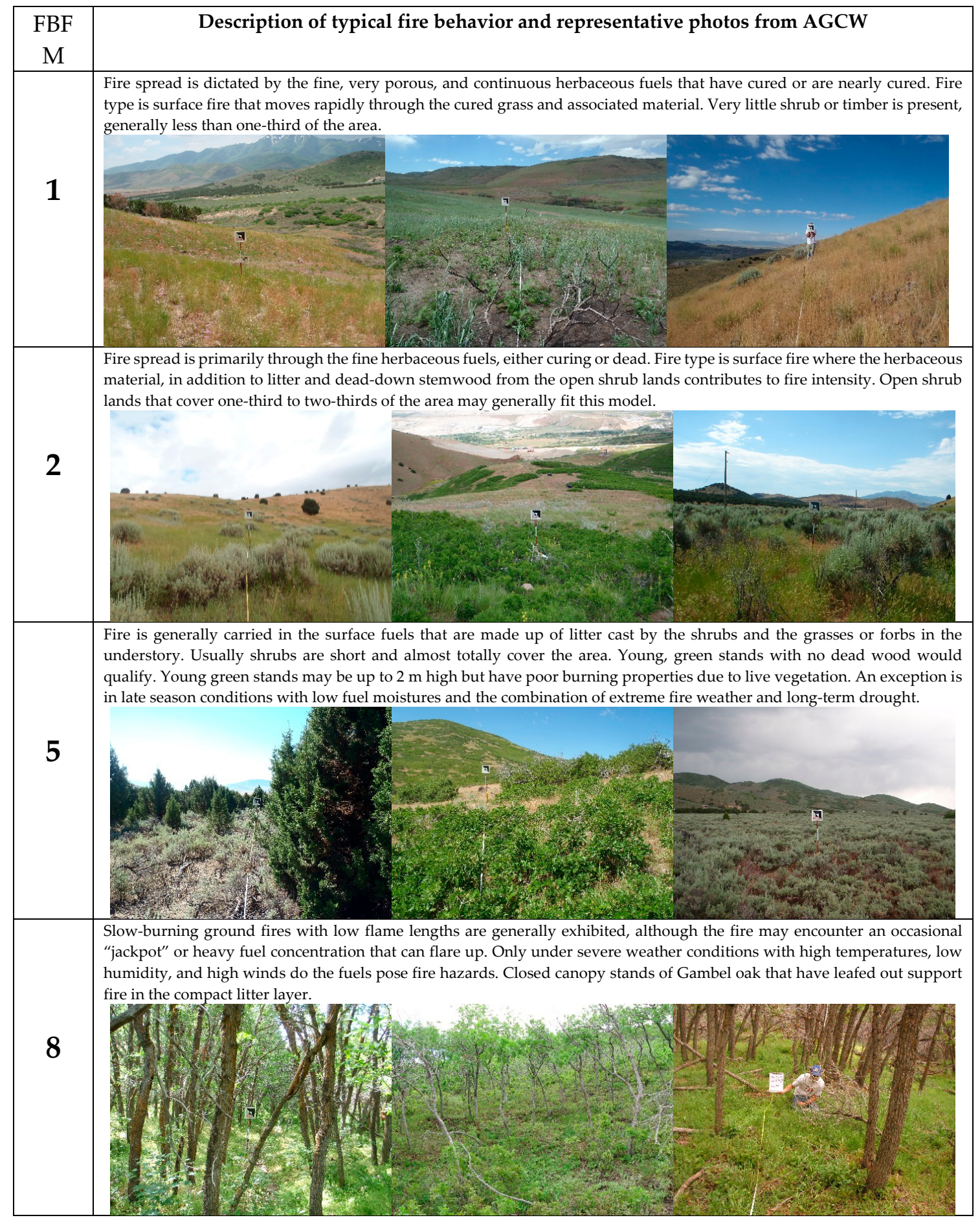

Figure A2. Typical fire behavior and representative photos associated with the primary fire behavior fuel models (FBFM) described by Anderson [32] found at Army Garrison Camp Williams.

\section{References}

1. Countryman, C.M. Fire environment and silvicultural practice. In Proceedings of the Society of American Foresters Annual Meeting, San Francisco, CA, USA, 15-19 November 1959; pp. 22-23.

2. Countryman, C.M. Mass Fires and Fire Behavior. In Research Paper; PSW-19; USDA Forest Service, Pacific Southwest Forest and Range Experiment Station: Berkeley, CA, USA, 1964; pp. 1-53.

3. Countryman, C.M. The concept of fire environment. Fire Control Notes 1966, 27, 8-10. 
4. Countryman, C.M. Fuel evaluation for fire control and fire use. In Proceedings of the Symposium of Fire Ecology and the Control and Use of Fire in Wild Land Management, Tucson, AZ, USA, 19 April 1969; Wagle, R.F., Ed.; University of Arizona: Tucson, AZ, USA, 1969; pp. 30-38.

5. Countryman, C.M. The Fire Environment Concept; USDA Forest Service, Pacific Southwest Forest and Range Experiment: Berkeley, CA, USA, 1972; pp. 1-12.

6. Countryman, C.M. The fire environment concept. Fire Manag. 1973, $34,17$.

7. Countryman, C.M.; Schroeder, M.J. Fire environment-The key to fire behavior. In Proceedings of the Fifth World Forestry Congress, Seattle, WA, USA, 29 August-10 September 1960; USDA Forest Service: Washington, DC, USA, 1962; Volume 2, pp. 860-863.

8. Brown, A.A.; Davis, K.P. Forest Fire: Control and Use, 2nd ed.; McGraw-Hill: New York, NY, USA, $1973 ;$ p. 686.

9. Keane, R.E. Wildland Fuel Fundamentals and Applications; Springer: Cham, Switzerland; Berlin, Germany, 2015; p. 191.

10. Merrill, D.F.; Alexander, M.E. (Eds.) Glossary of Forest Fire Management Terms, 4th ed.; National Research Council of Canada Publication NRCC No. 26516; Canadian Committee on Forest Fire Management: Ottawa, ON, Canada, 1987; pp. 1-91.

11. Rothermel, R.C. A mathematical model for predicting fire spread in wildland fuels. In USDA Forest Service Research Paper; INT-115; Intermountain Forest and Range Experiment Station: Ogden, UT, USA, 1972; pp. 1-40.

12. Deeming, J.E.; Brown, J.K. Fuel models in the national fire-danger rating system. J. For. 1975, 73, 347-350.

13. Fosberg, M.A. Drying rates of heartwood below fiber saturation. For. Sci. 1970, 16, 57-63.

14. Fosberg, M.A.; Rothermel, R.C.; Andrews, P.L. Moisture content calculations for 1000-hour timelag fuels. For. Sci. 1981, 27, 19-26.

15. Brown, J.K. Handbook for inventorying downed woody material. In USDA Forest Service, General Technical Report; GTR-INT-16; Intermountain Forest and Range Experiment Station: Ogden, UT, USA, 1974; pp. 1-24.

16. Deeming, J.E.; Burgan, R.W.; Cohen, J.D. The National Fire-Danger Rating System-1978. In USDA Forest Service General Technical Report; INT-39; Intermountain Forest and Range Experiment Station: Ogden, UT, USA, 1977; pp. 1-63.

17. Barrows, J.S. Fire behavior in northern Rocky Mountain forests. In Station Paper; No. 29; US Department of Agriculture, Forest Service, Northern Rocky Mountain Forest and Range Experiment Station: Missoula, MT, USA, 1951; pp. 1-103.

18. Campbell, D. The Campbell Prediction System, 3rd ed.; Ojai Printing and Publishing Company: Ojai, CA, USA, 2005; p. 142.

19. Van, W.C. Effect of slope on fire spread rate. Canadian Forestry Service. Bi Mon. Res. Notes 1977, 33, 7-8.

20. Schroeder, M.J.; Buck, C.C. Fire Weather: A Guide for Application of Meteorological Information to Forest Fire Control Operations. In Agriculture Handbook 360; USDA Forest Service: Washington, DC, USA, 1970; pp. 1-299.

21. Cheney, N.P. Fire behaviour. In Fire and the Australian Biota; Gill, A.M., Groves, R.H., Noble, I.R., Eds.; Australian Academy of Science: Canberra, Australia, 1981; pp. 151-175.

22. Whiteman, C.D. Mountain Meteorology: Fundamentals and Applications; Oxford University Press: New York, NY, USA, 2000; p. 355.

23. Nelson, R.M., Jr. Water relations of forest fuels. In Forest Fires: Behavior and Ecological Effects; Johnson, E.A., Miyanishi, K., Eds.; Academic Press: San Diego, CA, USA, 2001; pp. 79-149.

24. Frost, S.M. Fire Environment Analysis at Army Garrison Camp Williams in Relation to Fire Behavior Potential for Gauging Fuel Modification Needs. Master's Thesis, Utah State University, Logan, UT, USA, 2015; p. 183.

25. Ryan, B.C. Potential Fire Behavior in California: An Atlas and Guide for Forest and Brushland Managers; Gen. Tech. Rep. PSW-77; US Department of Agriculture, Forest Service, Pacific Southwest Forest and Range Experiment Station: Berkley, CA, USA, 1984; pp. 1-15.

26. Keane, R.E.; Burgan, R.; Van Wagtendonk, J.W. Mapping wildland fuels for fire management across multiple scales: Integrating remote sensing, GIS and biophysical modeling. Int. J. Wildland Fire 2001, 10, 301-319. [CrossRef]

27. Ottmar, R.D.; Vihnanek, R.E.; Wright, C.S. Stereo photo series for quantifying natural fuels Volume X: Sagebrush with grass and ponderosa pine-juniper types in central Montana. In USDA Forest Service General Technical Report; PNW-GTR-719; Pacific Northwest Research Station: Portland, OR, USA, 2007; p. 59. 
28. Ottmar, R.D.; Vihnanek, R.E.; Wright, C.S. Stereo Photo Series for Quantifying Natural Fuels. Volume III: Lodgepole Pine, Quaking Aspen, and Gambel Oak Types in the Rocky Mountains; Publication NFES 2629; National Wildfire Coordinating Group, National Fire Equipment System, National Interagency Fire Center: Boise, ID, USA, 2000; pp. 1-85.

29. Ottmar, R.D.; Vihnanek, R.E.; Regelbrugge, J.C. Stereo Photo Series for Quantifying Natural Fuels. Volume IV: Pinyon-Juniper, Sagebrush, and Chaparral Types in the Southwestern United States; Publication NFES 1084; National Wildfire Coordinating Group, National Fire Equipment System, National Interagency Fire Center: Boise, ID, USA, 2000; pp. 1-97.

30. Ottmar, R.D.; Vihnanek, R.E.; Wright, C.S. Stereo Photo Series for Quantifying Natural Fuels. Volume I: Mixed-Conifer with Mortality, Western Juniper, Sagebrush, and Grassland Types in the Interior Pacific Northwest; Publication NFES 2580; National Wildfire Coordinating Group, National Fire Equipment System, National Interagency Fire Center: Boise, ID, USA, 1998; pp. 1-73.

31. Scott, J.H.; Burgan, R.E. Standard fire behavior models: A comprehensive set for use with Rothermel's surface fire spread model. In USDA Forest Service General Technical Report; RMRS-GTR-153; Rocky Mountain Research Station: Fort Collins, CO, USA, 2005; pp. 1-72.

32. Anderson, H.E. Aids to determining fuel models for estimating fire behavior. In USDA Forest Service General Technical Report; INT-122; Intermountain Forest Range and Experiment Stations: Ogden, UT, USA, 1982; pp. 1-22.

33. Ziel, R.; Jolly, W.M. Performance of fire behavior fuel models developed for the Rothermel surface fire spread model. In Proceedings of the 3rd Fire in Eastern Oak Forests Conference, Carbondale, IL, USA, 20-22 May 2008; Proc. NRS-P-46. US Department of Agriculture, Forest Service, Northern Research Station: Newtown Square, PA, USA, 2009; pp. 78-87.

34. Cutler, D.R.; Edwards, T.C., Jr.; Beard, K.H.; Cutler, A.; Hess, K.T.; Gibson, J.; Lawler, J.J. Random forests for classification in ecology. Ecology 2007, 88, 2783-2792. [CrossRef] [PubMed]

35. USFS-WFAS United States Forest Service-Wildland Fire Assessment System. National Fuel Moisture Database. 2014. Available online: https://www.wfas.net/index.php/national-fuel-moisture-database-moisture-drought103 (accessed on 15 March 2014).

36. Quick Terrain Modeler [QT Modeler]; Applied Imagery: Silver Spring, MA, USA, 2013.

37. ESRI. ArcGIS; Environmental Systems Research Institute: Redlands, CA, USA, 2012.

38. Bradshaw, L.S.; Deeming, J.E.; Burgan, R.E.; Cohen, J.D. The 1978 National Fire-Danger Rating System: Technical Documentation; U.S. Department of Agriculture, Forest Service, Intermountain Forest and Range Experiment Station: Ogden, UT, USA, 1983; pp. 1-44.

39. Rothermel, R.C. How to Predict the Spread and Intensity of Forest and Range Fires; USDA Forest Service, Intermountain Forest and Range Experiment Station: Ogden, UT, USA, 1983; Volume 143, pp. 1-161.

40. [NWCG] National Wildfire Coordinating Group. NWCG Standards for Fire Weather Stations. Interagency Wildfire Fire Weather Station Standards and Guidelines; Publication Management System Publication PMS 426-3; National Interagency Fire Center: Boise, ID, USA, 2019; pp. 1-46.

41. Bradshaw, L.S.; McCormick, E. Fire Family Plus User's Guide, Version 3.0; USDA Forest Service, Rocky Mountain Research Station, Missoula Fire Sciences Laboratory: Missoula, MT, USA, 2004; pp. 1-124.

42. R Core Team. R: A Language and Environment for Statistical Computing; R Foundation for Statistical Computing: Vienna, Austria, 2013.

43. Short, K.C. Spatial Wildfire Occurrence Data for the United States, 1992-2012, 2nd ed.; [FPA_FOD_20140428]; USDA Forest Service, Rocky Mountain Research Station, Research Data Archive: Fort Collins, CO, USA, 2014.

44. Western Regional Climate Center [WRCC]. RAWS USA Climate Archive. Available online: http://www.raws. dri.edu/ (accessed on 15 September 2014).

45. Huschke, R.E. Glossary of Meteorology; American Meteorological Society: Boston, MA, USA, 1959; p. 638.

46. List, R.J. Smithsonian meteorological tables. In Smithsonian Miscellaneous Collections; Smithsonian Institute: Washington, DC, USA, 1951.

47. NOAA. National Oceanic and Atmospheric Administration. National Climatic Data Center. Available online: http://www.ncdc.noaa.gov/ (accessed on 15 March 2014).

48. Andrews, P.L.; Bradshaw, L.S.; Bunnell, D.; Curcio, G.M. Fire danger rating pocket card for firefighter safety. In Preprints of Second Conference on Fire and Forest Meteorology, Phoenix, AZ, USA, 11-16 January 1998; American Meteorological Society: Boston, MA, USA, 1998; pp. 67-70. 
49. Reeves, M.C.; Ryan, K.C.; Rollins, M.G.; Thompson, T.G. Spatial fuel data products of the LANDFIRE roject. Int. J. Wildland Fire 2009, 18, 250-267. [CrossRef]

50. Finney, M.A. A computational method for optimising fuel treatment locations. Int. J. Wildland Fire 2007, 16, 702. [CrossRef]

51. Finney, M.A. An Overview of FlamMap Fire Modeling Capabilities. In Proceedings of the Fuels Management-How to Measure Success: Conference Proceedings, Portland, OR, USA, 28-30 March 2006; Proc. RMRS-P-41. US Department of Agriculture, Forest Service, Rocky Mountain Research Station: Fort Collins, CO, USA, 2006; pp. 213-220.

52. Ahmed, R.M.; Hassan, K.Q.; Abdollahi, M.; Gupta, A. Introducing a new remote sensing-based model for forecasting forest fire danger conditions at a four-day scale. Remote Sens. 2019, 11, 2101. [CrossRef]

53. Matin, M.A.; Chitale, V.S.; Murthy, M.S.R.; Uddin, K.; Bajracharya, B.; Pradhan, S. Understanding forest fire patterns and risk in Nepal using remote sensing, geographic information system and historical fire data. Int. J. Wildland Fire 2017, 26, 276-286. [CrossRef]

54. Brown, T.J.; Hall, B.L.; Westerling, A.L. The impact of twenty-first century climate change on wildland fire danger in the western United States: An applications perspective. Clim. Chang. 2004, 62, 365-388. [CrossRef]

55. Rollins, M.G.; Frame, C.K. The LANDFIRE Prototype Project: Nationally Consistent and Locally Relevant Geospatial Data for Wildland Fire Management; Gen. Tech. Rep. RMRS-GTR-175; US Department of Agriculture, Forest Service, Rocky Mountain Research Station: Fort Collins, CO, USA, 2006; pp. 1-416.

56. Van Wagtendonk, J.W.; Root, R.R. The use of multi-temporal Landsat Normalized Difference Vegetation Index (NDVI) data for mapping fuel models in Yosemite National Park, USA. Int. J. Remote Sens. 2003, 24, 1639-1651. [CrossRef]

57. Streutker, D.R.; Glenn, N.F. LiDAR measurement of sagebrush steppe vegetation heights. Remote Sens. Environ. 2006, 102, 135-145. [CrossRef]

58. Bond, P.I. Sagebrush Steppe Shrub Height and Canopy Cover Estimation Using LiDAR and Landsat 5 TM Data. Ph.D. Thesis, University of Idaho, Moscow, ID, USA, 2011; p. 93.

59. Bork, E.W.; Su, J.G. Integrating LIDAR data and multispectral imagery for enhanced classification of rangeland vegetation: A meta analysis. Remote Sens. Environ. 2007, 111, 11-24. [CrossRef]

60. Jensen, J.R. Introductory Digital Image Processing, 3rd ed.; Pearson Prentice Hall: Saddle River, NJ, USA, 2005; p. 544 .

(C) 2020 by the authors. Licensee MDPI, Basel, Switzerland. This article is an open access article distributed under the terms and conditions of the Creative Commons Attribution (CC BY) license (http://creativecommons.org/licenses/by/4.0/). 